\title{
KARAKTERISTIK HIDRODINAMIK DESAIN LAMBUNG KAPAL DENGAN RISE OF FLOOR DAN TANPA RISE OF FLOOR PADA PERAIRAN DALAM DAN DANGKAL
}

\author{
Bambang Sudjasta ${ }^{1}$, Wiwin Sulistyawati ${ }^{2}$ \\ Prodi Teknik Perkapalan, Universitas Pembangunan Nasional "Veteran" Jakarta, Jakarta Selatan, Indonesia1 2 \\ email ${ }^{1}$ : bambangsudjasta58@gmail.com
}

\begin{abstract}
In principle Manoeuvrability vessel is strongly influenced by the design of the hull, propulsion system and steering system. Some of these elements are directly give a significant effect on the hydrodynamic force and moment when the ship maneuver. Analysis of hydrodynamic aspects is a stage that is absolutely necessary in the design process of a ship, especially for ships operating in waters with varying depths. By the time the ship through the shallow waters can increase frictional resistance surge barriers and the vessel which resulted in a decrease in speed boats. The hull form with rise of floor and without the rise of floor by focusing on the analysis of the obstacles, the character of the ship motion and acceleration criteria in deep and shallow water conditions. In numerical calculations for shallow water conditions (shallow water) with a ratio of water depth and draft of the ships, $h / d=1.2$ and deep water (deep water) with $h$ $/ d=20$. Evaluation of the obstacles, the character motion and acceleration for heave, roll, pitch and yaw is done by combining numerical methods through Hullspeed and AQWA Ansys program. From this numerical calculation, it can be analyzed with the rise of the hull form floor and without a rise of floor optimum for deepwater and shallow.
\end{abstract}

Keywords: Manoeuvrability, shallow water, obstacles, motion, acceleration.

\section{PENDAHULUAN}

\section{Latar Belakang}

Beberapa industri di Indonesia menggunakan moda transportasi kapal sebagai sarana dalam pendistribusian produksinya. Dengan kondisi perairan pada kedalaman yang bervariasi, beberapa kapal didesain untuk berlayar di laut lepas dengan kondisi perairan yang dalam, sekaligus harus dapat menjangkau perairan dangkal seperti sungai. Kapalkapal yang beroperasi di perairan dangkal pada prinsipnya menggunakan pendekatan yang sama seperti halnya kapal-kapal yang beroperasi di laut. Prinsip manoeuvrability jenis kapal apapun sangat dipengaruhi oleh desain badan / lambung, sistem propulsi, dan sistem kemudi. Elemen-elemen tersebut secara langsung memberi pengaruh yang signifikan terhadap gaya dan momen hidrodinamika saat kapal bermanuver.

\section{Permasalahan}

Namun terdapat beberapa perbedaan yaitu dalam pelayaran terdapat batasan kedalaman, dimensi dan olah gerak kapal. Kapal yang berlayar di perairan sempit dan dangkal akan menimbulkan ombak haluan yang mengalir ke belakang. Di mana arus buritan mengalir ke depan, sehingga ombak buritan yang mendorong kapal. Apabila pada kecepatan tinggi kemungkinan lunasnya akan menyentuh dasar perairan/kandas.

\section{Tujuan}

a. Melakukan pembuatan model kapal dengan program Maxsurf 13.01.

b. Melakukan analisis hambatan dengan menggunakan program Hullspeed.

c. Melakukan analisis karakter motion dan acceleration model dengan menggunakan program ansys AQWA.

d. Melakukan evaluasi perhitungan numerik hambatan, karakter motion dan acceleration model.

Menemukan titik optimal bentuk lambung kapal pada perairan dalam dan dangkal.

\section{TINJAUAN PUSTAKA \\ Analisis Hidrodinamika}

Bentuk lambung kapal menentukan besarnya hambatan kapal yang berdampak pada kecepatan kapal. Sedangkan manoeuvrability kapal sangat dipengaruhi oleh perancangan badan kapal, sistem propulsi dan sistem kemudi. Sejumlah elemen tersebut secara langsung memberi pengaruh yang signifikan terhadap gaya dan momen hidrodinamika 
saat kapal bermanuver. IMO (International Maritime

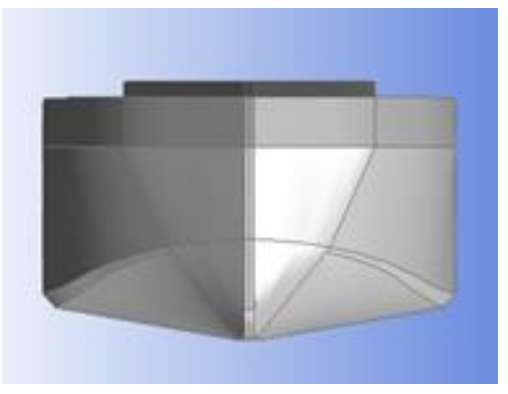

With rise of floor

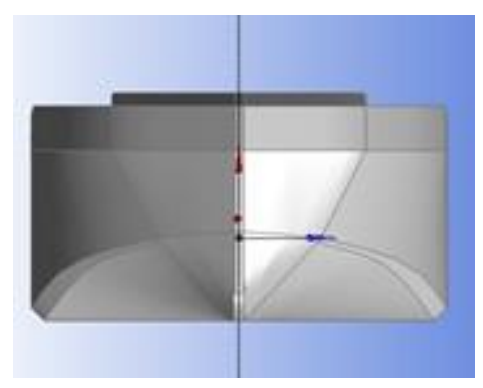

Without rise of floor

Gambar 1. Bentuk lambung kapal dengan rise of floor dan tanpa rise of floor.

Organization) telah merekomendasikan beberapa kriteria standar untuk manuverabilitas kapal. Kriteria tersebut harus dipenuhi oleh sebuah kapal saat beroperasi baik di perairan yang dalam (deep water) maupun di perairan terbatas atau beroperasi di sekitar pelabuhan atau di perairan yang dangkal (restricted and shallow water).

Dampak dari kapal memasuki perairan dangkal adalah pengurangan kecepatan dan squat pengurangan jarak ruang antara lunas kapal dan dasar laut yang disebabkan oleh gerak relatif bentuk badan kapal yang terbenam dalam air.

\section{Hipotesis}

Perhitungan numerik dari karakteristik hidrodinamik desain lambung dengan rise of floor dan tanpa rise of floor pada perairan dalam dan dangkal dapat menghasilkan desain lambung yang optimum. Sehingga dapat memprediksi hambatan dan perkiraan kemampuan seakeeping kapal baik pada perairan dalam maupun dangkal.

\section{METODOLOGI PENELITIAN Identifikasi Data}

a. Studi literatur

b. Data penelitian model eksperimen sebelumnya

\section{Pemodelan}

Pemodelan kapal dengan menggunakan program Maxsurf 13.01. Dimana proses desain kapal didasarkan pada lines plan model eksperimen.

Analisis Model

Analisis dilakukan dengan melakukan perhitungan hambatan dengan menggunakan program Hullspeed. Selanjutnya dilakukan analisis motion dan acceleration kapal dengan menggunakan ansys AQWA.

\section{Diagram Metodologi Penelitian}

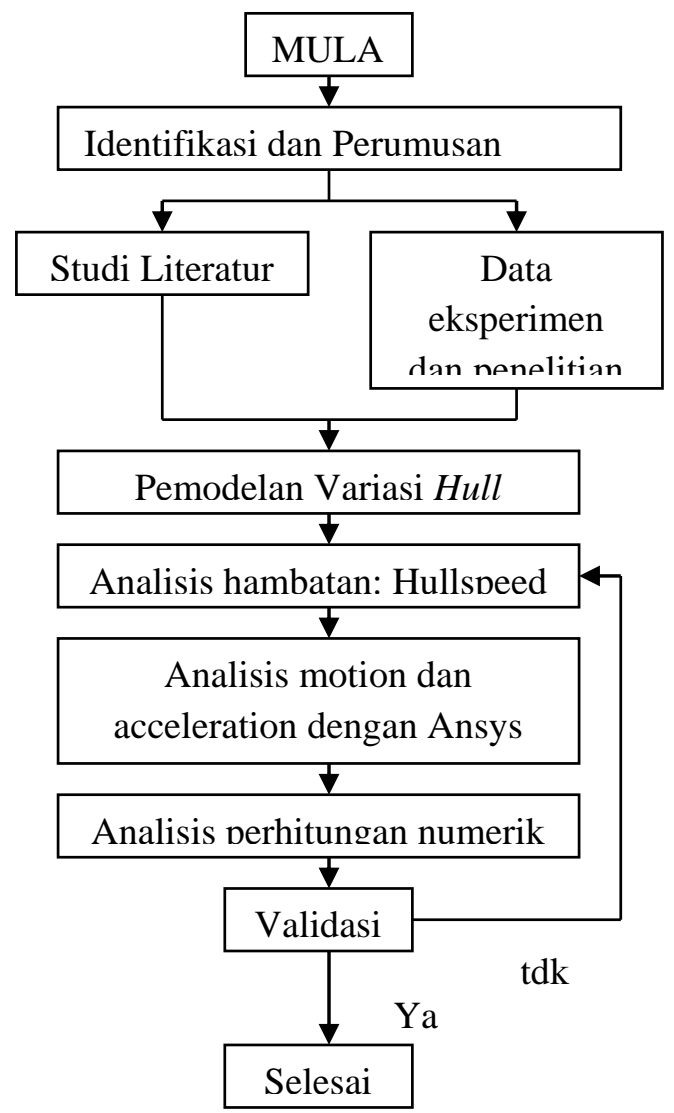

Gambar 2. Diagram Metode Penelitian

\section{Evaluasi Perhitungan Numerik}

Evaluasi motion dan acceleration dititikberatkan pada menghitung besarnya nilai RAO (Response amplitude operator) pada heave, roll dan pitch dan yaw, serta kriteria acceleration pada arah gelombang (wave direction): $0^{\circ}, 45^{\circ}, 90^{\circ}$, dan $180^{\circ}$.

\section{HASIL DAN PEMBAHASAN \\ Model Bentuk Lambung Kapal}

Model bentuk lambung kapal dengan rise of floor (RF 1) dan tanpa rise of floor (RF 0) seperti pada Gambar 2 dan 3. Adapun ukuran utama kapal yang digunakan adalah:

$$
\begin{array}{llr}
- \text { Panjang }(L W L) & =12,00[\mathrm{~m}] \\
- \text { Lebar }(\mathrm{B}) & = & 3,00[\mathrm{~m}] \\
- \text { Tinggi }(\mathrm{H}) & = & 2,00[\mathrm{~m}] \\
- \text { Sarat }(\mathrm{T}) & = & 0,60[\mathrm{~m}]
\end{array}
$$


- Kecepatan $=10[\mathrm{knot}]$

Kecocokan model dalam segi ukuran utama kapal dan karakteristik kapal dengan melihat pada item calculate hydrostatic pada Maxsurf seperti pada Tabel 1 dan Tabel 2.

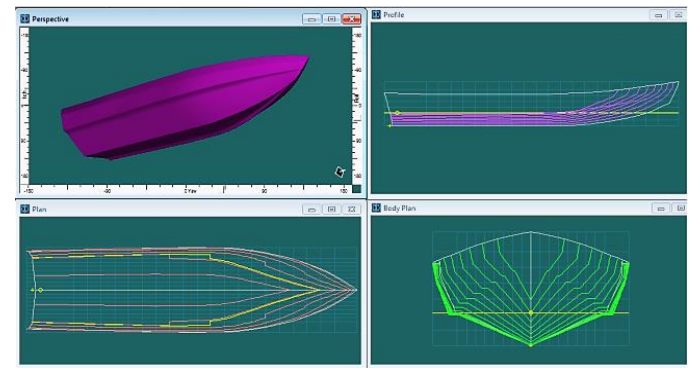

Gambar 3a. Model hull dengan rise of floor (RF 1)
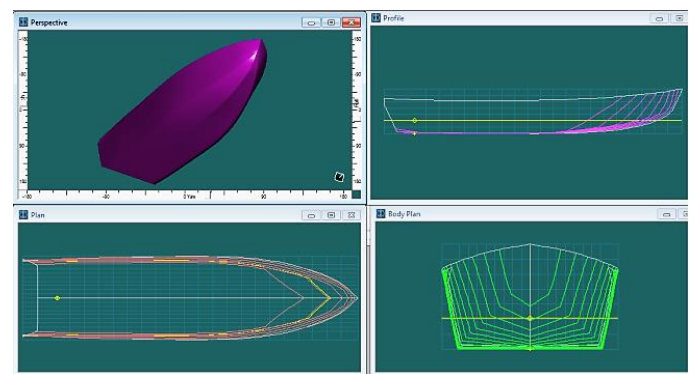

Gambar 3b. Model hull tanpa rise of floor (RF 0)

Tabel 1. Perbandingan nilai prosentase data kapal model hull dengan rise of floor (RF 1)

\begin{tabular}{|c|l|r|r|r|r|}
\hline No & \multicolumn{1}{|c|}{ Item } & \multicolumn{1}{c|}{$\begin{array}{c}\text { Data } \\
\text { Kapal }\end{array}$} & $\begin{array}{c}\text { Data } \\
\text { Model }\end{array}$ & \multicolumn{1}{c|}{$\begin{array}{c}\text { Selisi } \\
\mathbf{h}\end{array}$} & $(\%)$ \\
\hline 1 & $\begin{array}{l}\text { Displacement } \\
\text { (ton) }\end{array}$ & 16,35 & 15,683 & 0,67 & 4,08 \\
\hline 2 & Volume $\left(\mathrm{m}^{3}\right)$ & 15,95 & 15,300 & 0,65 & 4,08 \\
\hline 3 & $\begin{array}{l}\text { Draft to } \\
\text { baseline (m) }\end{array}$ & 0,60 & 0,600 & 0,00 & 0,00 \\
\hline 4 & LWL (m) & 12,00 & 12,000 & 0,00 & 0,00 \\
\hline 5 & Beam WL (m) & 3,00 & 4,267 & 1,27 & 42,2 \\
3
\end{tabular}

Tabel 2. Perbandingan nilai prosentase data kapal model hull tanpa rise of floor (RF 0)

\begin{tabular}{|c|l|r|r|r|c|}
\hline No & \multicolumn{1}{|c|}{ Item } & $\begin{array}{c}\text { Data } \\
\text { Kapal }\end{array}$ & $\begin{array}{c}\text { Data } \\
\text { Model }\end{array}$ & \multicolumn{1}{c|}{$\begin{array}{c}\text { Selisi } \\
\mathbf{h}\end{array}$} & $(\%)$ \\
\hline 1 & $\begin{array}{l}\text { Displacement } \\
\text { (ton) }\end{array}$ & 16,35 & 15,683 & 0,67 & 4,08 \\
\hline 2 & Volume $\left(\mathrm{m}^{3}\right)$ & 15,95 & 15,301 & 0,65 & 4,07 \\
\hline 3 & $\begin{array}{l}\text { Draft to } \\
\text { baseline (m) }\end{array}$ & 0,60 & 0,600 & 0,00 & 0,00 \\
\hline 4 & LWL (m) & 12,00 & 12,000 & 0,00 & 0,00 \\
\hline 5 & Beam WL (m) & 3,00 & 3,00 & 0,00 & 0,00 \\
\hline
\end{tabular}

Model dan data kapal ditekankan pada kesamaan displacement dengan koreksi perbedaan $<5 \%$ sehingga dapat dikatakan model sudah memenuhi untuk dilakukan analisis selanjutnya.

\section{Perhitungan Hambatan}

Perhitungan hambatan menggunakan software hullspeed berdasarkan persyaratan kriteria penggunaan algorithma hambatan pada Tabel 3.

Tabel 3. Kriteria numerik pemilihan algorithma

\begin{tabular}{|c|c|c|c|c|c|}
\hline Algorithm & \multicolumn{5}{|c|}{ Requirement } \\
\hline \multirow{6}{*}{ Savitsky } & 3.07 & $<$ & $\mathrm{L} / \mathrm{V} 1 / 3$ & $<$ & 12.4 \\
\hline & 3.7 & $<$ & ie & $<$ & 28.6 \\
\hline & 2.52 & $<$ & $\mathrm{L} / \mathrm{B}$ & $<$ & 18.26 \\
\hline & 1.7 & $<$ & $\mathrm{B} / \mathrm{T}$ & $<$ & 9.8 \\
\hline & 0 & $<$ & $\mathrm{At} / \mathrm{Ax}$ & $<$ & 1 \\
\hline & -0.016 & $<$ & LCG/L & $<$ & 0.0656 \\
\hline \multirow{6}{*}{$\begin{array}{c}\text { Lahtiharj } \\
\text { u } \\
\text { (Round } \\
\text { Bilge) }\end{array}$} & 4.47 & $<$ & $\mathrm{L} / \mathrm{V} 1 / 3$ & $<$ & 8.3 \\
\hline & 0.68 & $<$ & $\mathrm{B} 3 / \mathrm{V}$ & $<$ & 7.76 \\
\hline & 3.33 & $<$ & $\mathrm{L} / \mathrm{B}$ & $<$ & 8.21 \\
\hline & 1.72 & $<$ & $\mathrm{B} / \mathrm{T}$ & $<$ & 10.21 \\
\hline & 0.16 & $<$ & $\mathrm{At} / \mathrm{Ax}$ & $<$ & 0.82 \\
\hline & 0.57 & $<$ & $\mathrm{Cm}$ & $<$ & 0.89 \\
\hline \multirow{4}{*}{$\begin{array}{c}\text { Lahtiharj } \\
\text { u } \\
\text { (Hard } \\
\text { Chine) }\end{array}$} & 4.49 & $<$ & $\mathrm{L} / \mathrm{V} 1 / 3$ & $<$ & 6.81 \\
\hline & 2.73 & $<$ & $\mathrm{L} / \mathrm{B}$ & $<$ & 5.43 \\
\hline & 3.75 & $<$ & $\mathrm{B} / \mathrm{T}$ & $<$ & 7.54 \\
\hline & 0.43 & $<$ & $\mathrm{At} / \mathrm{Ax}$ & $<$ & 0.995 \\
\hline \multirow{3}{*}{ Holtrop } & 0.55 & $<$ & $\mathrm{Cp}$ & $<$ & 0.85 \\
\hline & 3.9 & $<$ & $\mathrm{L} / \mathrm{B}$ & $<$ & 15 \\
\hline & 2.1 & $<$ & $\mathrm{B} / \mathrm{T}$ & $<$ & 4 \\
\hline \multirow{8}{*}{$\begin{array}{c}\text { van } \\
\text { Oortmers } \\
\text { sen }\end{array}$} & 8 & $<$ & $\mathrm{L}$ & $<$ & 80 \\
\hline & 3 & $<$ & $\mathrm{L} / \mathrm{B}$ & $<$ & 6.2 \\
\hline & 0.5 & $<$ & $\mathrm{Cp}$ & $<$ & 0.73 \\
\hline & -7 & $<$ & $100 \mathrm{LCG} / \mathrm{L}$ & $<$ & 2.8 \\
\hline & 5 & $<$ & V & $<$ & 3000 \\
\hline & 1.9 & $<$ & $\mathrm{B} / \mathrm{T}$ & $<$ & 4 \\
\hline & 0.7 & $<$ & $\mathrm{Cm}$ & $<$ & 0.97 \\
\hline & 10 & $<$ & ie & $<$ & 46 \\
\hline \multirow{4}{*}{ Series 60} & 0.6 & $<$ & $\mathrm{Cb}$ & $<$ & 0.8 \\
\hline & 5.5 & $<$ & $\mathrm{L} / \mathrm{B}$ & $<$ & 8.5 \\
\hline & 2.5 & $<$ & $\mathrm{B} / \mathrm{T}$ & $<$ & 3.5 \\
\hline & $-2.48 \%$ & $<$ & LCB & $<$ & $3.51 \%$ \\
\hline \multirow{5}{*}{ Delft } & 2.76 & $<$ & $\mathrm{L} / \mathrm{B}$ & $<$ & 5 \\
\hline & 2.46 & $<$ & $\mathrm{B} / \mathrm{T}$ & $<$ & 19.32 \\
\hline & 4.34 & $<$ & $\mathrm{L} / \mathrm{V} 1 / 3$ & $<$ & 8.5 \\
\hline & $-6.00 \%$ & $<$ & LCB & $<$ & $0.00 \%$ \\
\hline & 0.52 & $<$ & $\mathrm{Cp}$ & $<$ & 0.6 \\
\hline \multirow{3}{*}{ Compton } & -0.13 & $<$ & LCG/L & $<$ & -0.02 \\
\hline & 4 & $<$ & $\mathrm{L} / \mathrm{B}$ & $<$ & 5.2 \\
\hline & 0.0037 & $<$ & $\mathrm{V} / \mathrm{L}^{\wedge} 3$ & $<$ & 0.0053 \\
\hline \multirow{6}{*}{ Fung } & 0.0006 & $<$ & $\mathrm{V} / \mathrm{L}^{\wedge} 3$ & $<$ & 0.0126 \\
\hline & 1,696 & $<$ & $\mathrm{B} / \mathrm{T}$ & $<$ & 10,204 \\
\hline & 0.526 & $<$ & $\mathrm{Cp}$ & $<$ & 0.774 \\
\hline & 0.556 & $<$ & $\mathrm{Cx}$ & $<$ & 0.994 \\
\hline & $\begin{array}{r}14.324 \\
0\end{array}$ & $<$ & ie & $<$ & $\begin{array}{l}23.673 \\
0\end{array}$ \\
\hline & 2.52 & $<$ & $\mathrm{L} / \mathrm{B}$ & $<$ & 17,935 \\
\hline
\end{tabular}




\begin{tabular}{|l|l|l|l|l|l|}
\hline & 0.662 & $<$ & Cwp & $<$ & 0.841 \\
\hline
\end{tabular}

Model hull RF 0 berdasarkan tabel hasil kriteria algorithma yang relevan digunakan dalam perhitungan hambatan menggunakan metode: holtrop, van oortmeersen dan fung. Hasil analisis perhitungan hambatan dengan software hullspeed pada model hull RF 0 ditunjukkan grafik di bawah.

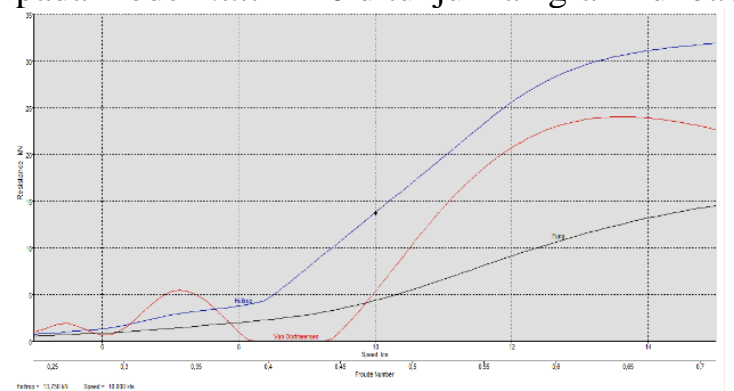

Gambar 4. Grafik besar hambatan terhadap kenaikan kecepatan pada hull RF 0

Model hull RF 5 berdasarkan tabel hasil kriteria algorithma yang relevan digunakan dalam perhitungan hambatan menggunakan metode: holtrop dan fung. Hasil analisis perhitungan hambatan dengan software hullspeed pada model hull RF 5 ditunjukkan gambar di bawah.

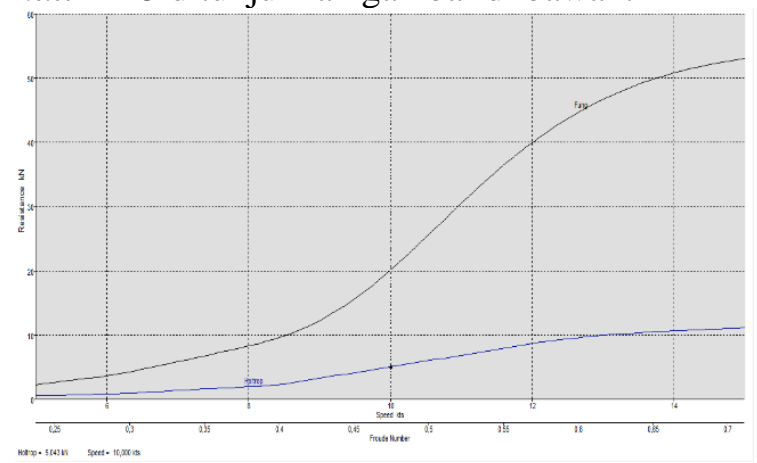

Gambar 5. Grafik besar hambatan terhadap kenaikan kecepatan pada hull RF 5

Rekapitulasi perbandingan besar hambatan dan power pada model hull tanpa rise of floor: RF 0 dengan model hull rise of floor: RF 1, RF 2, RF 3, RF 4, RF 5.

Tabel 4. Rekapitulasi besar hambatan dan power pada kecepatan 10 knot

\begin{tabular}{|l|r|r|r|r|r|r|}
\hline Model & RF 0 & RF 1 & RF 2 & RF 3 & RF 4 & RF 5 \\
\hline $\begin{array}{l}\text { Resistance } \\
\text { (Kn) }\end{array}$ & 13,75 & 7,3 & 12,1 & 10,3 & 7,35 & 5,04 \\
\hline $\begin{array}{l}\text { Power } \\
\text { (hp) }\end{array}$ & 145,93 & 50,39 & 128,41 & 109,3 & 77,96 & 53,53 \\
\hline
\end{tabular}

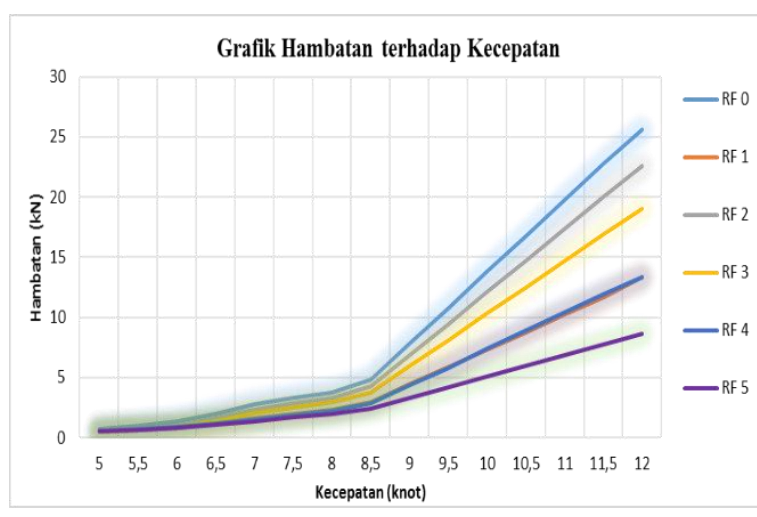

Gambar 6. Grafik perbandingan besar hambatan model hull

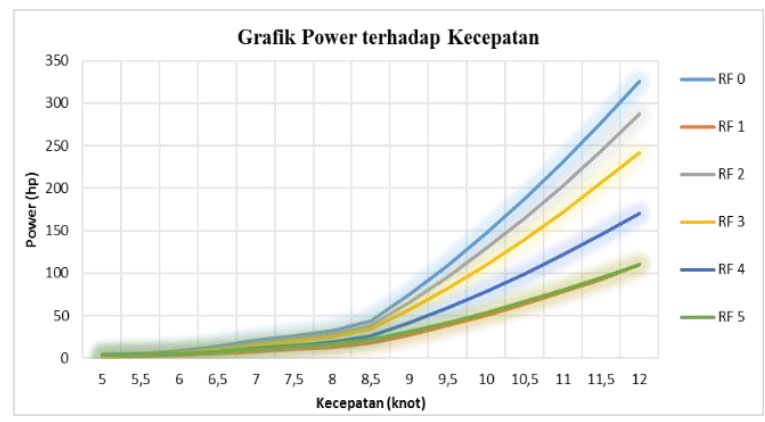

Gambar 7. Grafik perbandingan besar power model hull

Dari hasil analisis terhadap seluruh model hull didapatkan hambatan terkecil dihasilkan dari model hull RF 5 sebesar 5,04 kN, sedangkan power terkecil dihasilkan dari model hull RF 1 sebesar 50,39 hp.

\section{Koreksi Hambatan pada Perairan Dangkal}

Pada perairan dangkal dapat meningkatkan hambatan gelombang dan hambatan gesek pada kapal sebgai akibat dari efek squat sehingga mengakibatkan kapal mengalami penurunan kecepatan. Besarnya persentase penurunan kecepatan berdasarkan kurva dari Lackenby (1963) akibat dari perairan dangkal menggunakan formula dari Molland et al. (2011) yang dinyatakan pada persamaan dibawah ini:

$\Delta V / V=0.1242\left[\frac{A_{M}}{h^{2}}-0.05\right]+1-$

$\left[\tanh \left(\frac{g h}{V^{2}}\right)\right]^{0.5}$ Dari hasil perhitungan prosentase penurunan kecepatan selanjutnya dapat digunakan sebagai koreksi dalam perhitungan hambatan yang dialami oleh masing-masing model. Dengan power kapal yang tetap di perairan dalam maka koreksi resistance untuk kondisi perairan dangkal dengan perbandingan kedalaman air dan sarat kapal, $\mathrm{h} / \mathrm{d}=$ 1.2 ditunjukkan pada Tabel 5 . 
Tabel 5. Kenaikan resistance akibat kondisi perairan dangkal

\begin{tabular}{|c|r|r|r|r|}
\hline RF & $\begin{array}{c}\text { Resistance } \\
(\mathbf{k N})\end{array}$ & Koreksi & $\begin{array}{c}\text { Power } \\
(\mathbf{k W})\end{array}$ & $\begin{array}{c}\text { \% } \\
\text { Kenaikan } \\
\text { Resistance }\end{array}$ \\
\hline 0 & 13,75 & 109,29 & 108,864 & 87,42 \\
\hline 1 & 7,30 & 158,47 & 37,591 & 95,39 \\
\hline 2 & 12,10 & 118,12 & 95,794 & 89,76 \\
\hline 3 & 10,30 & 151,59 & 81,538 & 93,21 \\
\hline 4 & 7,35 & 302,46 & 58,158 & 97,57 \\
\hline 5 & 5,04 & 229,06 & 39,933 & 97,80 \\
\hline
\end{tabular}

Dari hasil koreksi pada Tabel 5 menunjukkan bahwa pada kondisi perairan yang dangkal $(\mathrm{h}=0,85 \mathrm{~m})$ maka hambatan kapal mengalami kenaikan yang besar. Perbandingan model hull yang paling kecil mengalami kenaikan hambatan ditunjukkan model hull RF 0.

\section{Kajian Hidrodinamika}

Validasi perlu dilakukan untuk memastikan bahwa hasil analisis dengan menggunakan model numerik adalah benar. Hasil pengujian dengan eksperimen dapat digunakan sebagai patokan karena kondisinya dianggap paling mendekati kondisi lapangan sebenarnya. Eksperimen yang dilakukan pada towing tank pada 3 kondisi perairan, meliputi perairan dangkal, sedang dan dalam menunjukkan bahwa hambatan terbesar dihasilkan pada perairan dangkal (Anggara, 2013). Hasil uji eksperimen yang dilakukan pada 3 kondisi perairan ditunjukkan Tabel dan Grafik .

Tabel 7. Hasil uji eksperimen untuk hambatan total

\begin{tabular}{|c|r|c|c|}
\hline \multirow{2}{*}{ Kecepatan } & \multicolumn{3}{|c|}{ Resistance (N) } \\
\cline { 2 - 4 } & \multicolumn{1}{|c|}{$\begin{array}{c}\text { Medium } \\
\text { Shallow }\end{array}$} & \multicolumn{1}{c|}{ Deep water } \\
\cline { 2 - 4 } & $\mathbf{h} / \mathbf{d}=\mathbf{1 . 2}$ & \multicolumn{1}{c|}{$\mathbf{h} / \mathbf{d}=\mathbf{2}$} & \multicolumn{1}{c|}{$\mathbf{h} / \mathbf{d}=\mathbf{2 0}$} \\
\hline 0.622 & 5.385 & 3.603 & 2.122 \\
\hline 0.700 & 6.799 & 4.524 & 2.719 \\
\hline 0.778 & 8.370 & 5.575 & 3.413 \\
\hline 0.856 & 10.287 & 6.742 & 4.187 \\
\hline
\end{tabular}

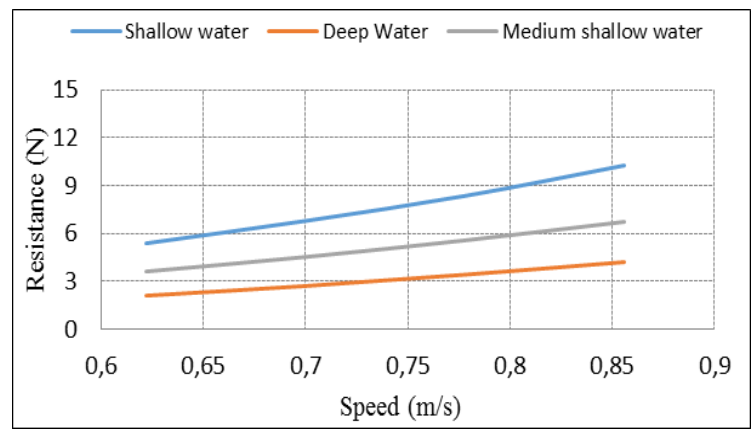

Gambar 8. Grafik uji eksperimen hambatan total pada 3 variasi kedalaman
Dari hasil eksperimen didapatkan bahwa selisih hambatan total antara deep water dengan medium shallow adalah $40 \%$ dan deep water dan shallow mencapai $60 \%$.

\section{Analisis Stabilitas}

Stabilitas kapal sangat ditentukan oleh beberapa faktor seperti bentuk badan kapal, berat dan letak titik berat pada saat kapal beroperasi (kondisi pemuatan). Kondisi kapal yang beroperasi selalu mengalami perubahan berat dan letak titik berat. Penilaian tentang stabilitas dilihat dari bentuk kurva stabilitas statis (kurva GZ), dimana GZ merupakan besarnya lengan pengembali kapal pada kondisi oleng tertentu. Sedangkan besarnya GZ tergantung dari besarnya KN (Cross Curve) dan KG (letak titik berat kapal). Kriteria stabilitas didasarkan pada persyaratan IMO (International Maritime Organization), INTACT STABILITY for all types of ship covered by IMO instrument resolution A.749 (18), Chapter 3.1 - General intact stability criteria for all ships.

\section{Analisis stabilitas pada model hull RF 0}

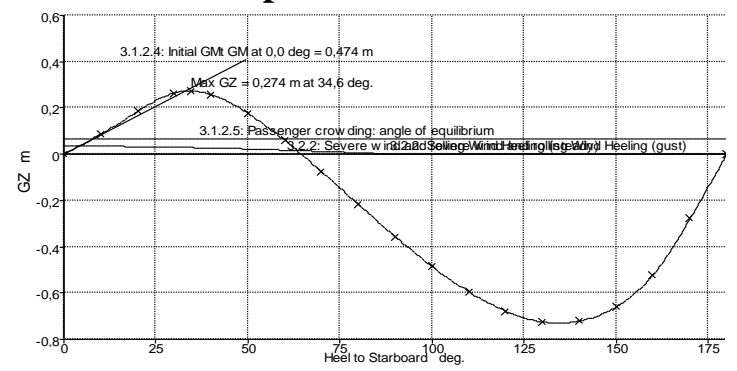

Gambar 9a. Grafilk stabilitas kondisi full load model RF 0

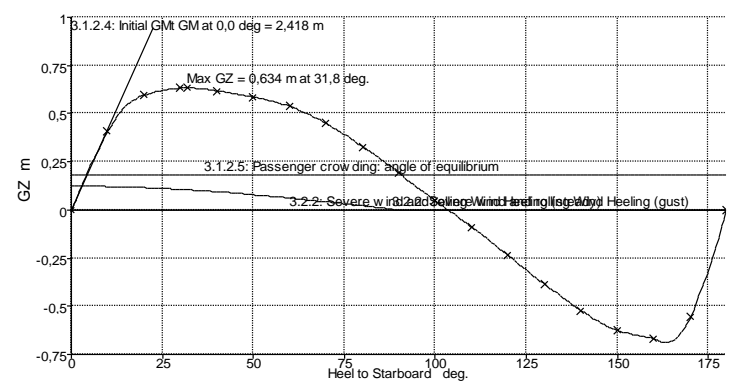

Gambar 9b. Grafilk stabilitas kondisi ballast arrival model RF 0

Dari hasil analisa stabilitas kondisi full load dan ballast arrival pada model RF 0 menunjukkan bahwa persyaratan stabilitas kapal memenuhi kriteria dari persyaratan IMO. 


\section{Analisis stabilitas pada model hull RF 1}

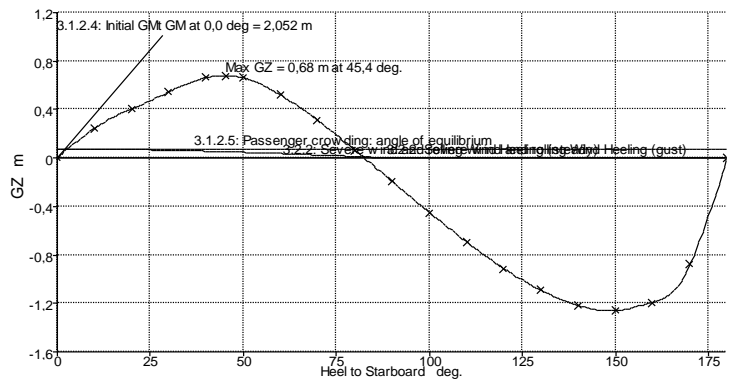

Gambar 10a. Grafilk stabilitas kondisi full load model RF 1

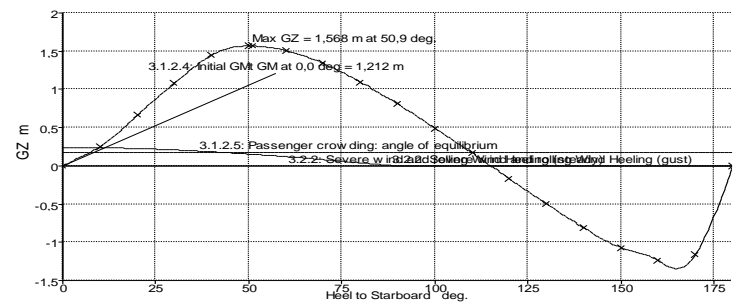

Gambar 10b. Grafilk stabilitas kondisi ballast arrival model RF 1

Dari hasil analisa stabilitas kondisi full load dan ballast arrival pada model RF 1 menunjukkan bahwa persyaratan stabilitas kapal memenuhi kriteria dari persyaratan IMO.

\section{Analisis stabilitas pada model hull RF 2}

Dari hasil analisa stabilitas kondisi full load dan ballast arrival pada model RF 2 menunjukkan bahwa persyaratan stabilitas kapal memenuhi kriteria dari persyaratan IMO.

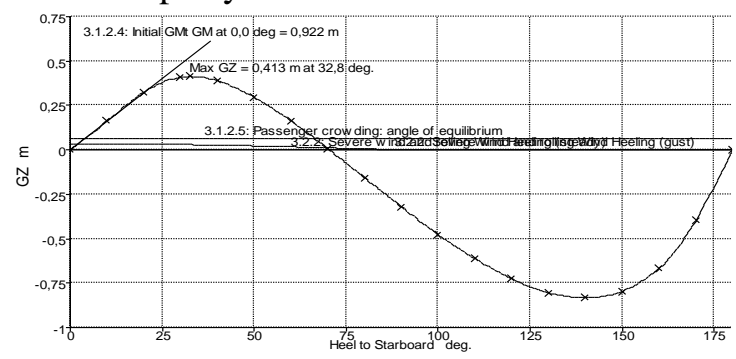

Gambar 11a. Grafilk stabilitas kondisi full load model RF 2

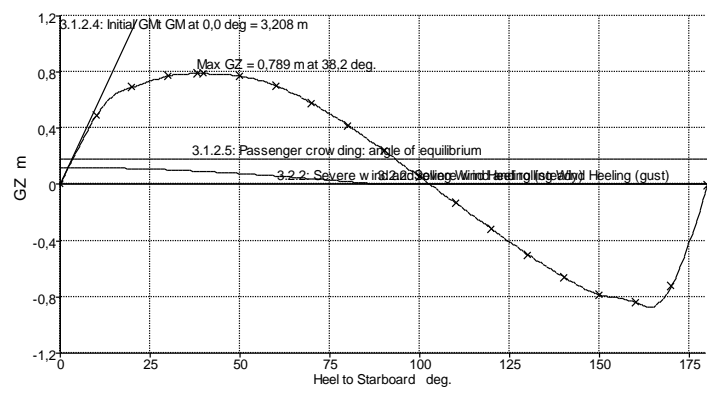

Gambar 11b. Grafilk stabilitas kondisi ballast arrival model RF 2
Analisis stabilitas pada model hull RF 3

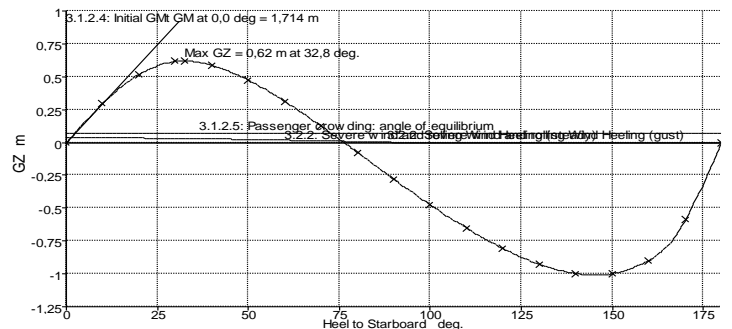

Gambar 12a. Grafilk stabilitas kondisi full load model RF 3

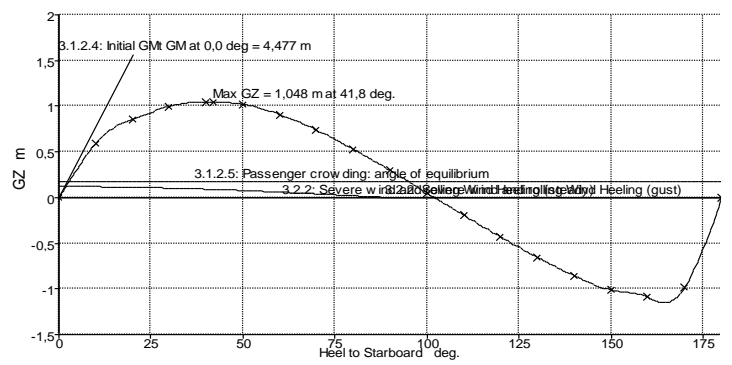

Gambar 12b. Grafilk stabilitas kondisi ballast arrival model RF 3

Dari hasil analisis stabilitas kondisi full load dan ballast arrival pada model RF 3 menunjukkan bahwa persyaratan stabilitas kapal memenuhi kriteria dari persyaratan IMO.

\section{Analisis stabilitas pada model hull RF 4}

Dari hasil analisa stabilitas kondisi full load dan ballast arrival pada model RF 4 menunjukkan bahwa persyaratan stabilitas kapal memenuhi kriteria dari persyaratan IMO.

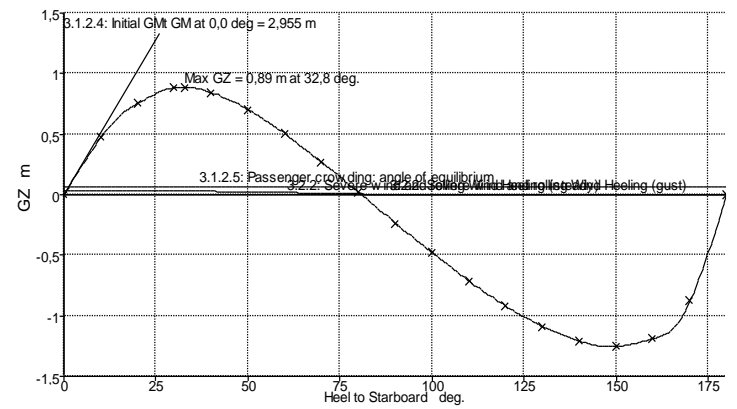

Gambar 13a. Grafilk stabilitas kondisi full load model RF 4

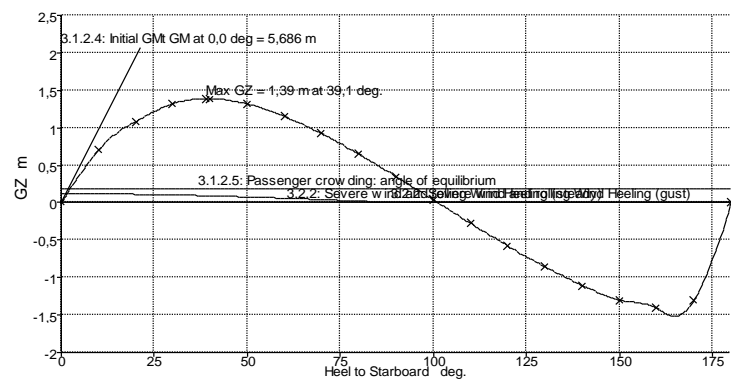

Gambar 13b. Grafilk stabilitas kondisi ballast arrival model RF 4 


\section{Analisis stabilitas pada model hull RF 5}

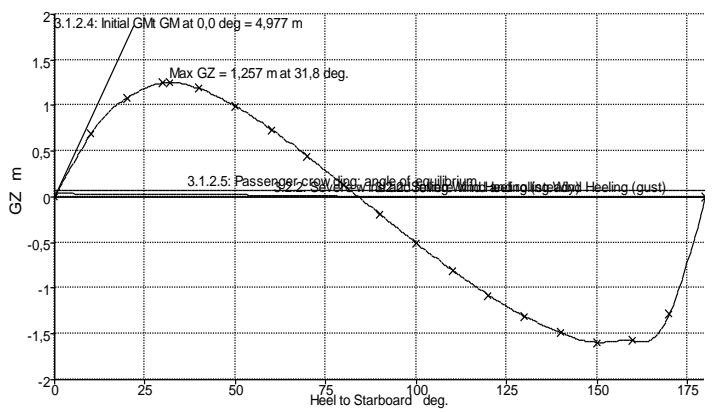

Gambar 14a. Grafilk stabilitas kondisi full load model RF 5

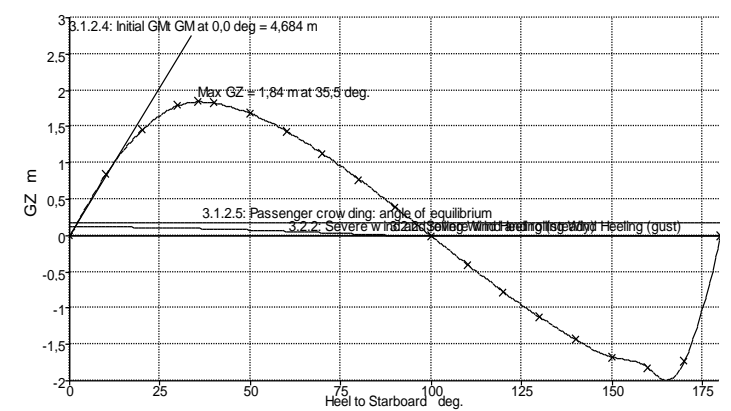

Gambar 14b. Grafilk stabilitas kondisi ballast arrival model RF 5

Dari hasil analisis stabilitas kondisi full load dan ballast arrival pada model RF 5 menunjukkan bahwa persyaratan stabilitas kapal memenuhi kriteria dari persyaratan IMO.

\section{Olah Gerak Kapal (Seakeeping)}

Pada dasarnya benda yang mengapung mempunyai enamderajat kebebasan(6 DOF) gerakan kapal terdiri dari tiga gerakan translasi dan tiga gerakan rotasi berdasarkan sumbu ordinat (Bhattacharya, 1978) yaitu:

$>$ Gerak translasional

- Surge, gerakan transversal arah sumbu x

- Sway, gerakan transversal arah sumbu y

- Heave, gerakan transversal arah sumbu z

Gerak rotasional

- Roll, gerakan rotasional arah sumbu x

- Pitch, gerakan rotasional arah sumbu y

- Yaw, gerakan rotasional arah sumbu z

Berdasarkan hasil perhitungan hambatan diketahui bahwa hambatan terkecil dihasilkan dari model hull RF 5 sebesar 5,04 kN, maka untuk analisis seakeeping dilakukan pada model RF 5. Input untuk respon analisis ditentukan:

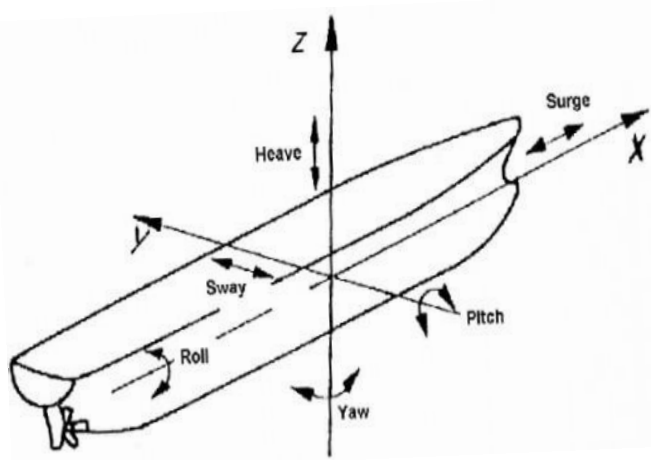

Gambar 15. Enam derajat kebebasan gerak kapal (Bhattacharya, 1978)

- Kedalaman perairan ditentukan sesuai dengan ketentuan minimum kedalaman untuk shallow water dimana $\mathrm{h} / \mathrm{T}=1.2$ atau $0,72 \mathrm{~m}$ dan massa jenisnya menggunakan massa jenis air tawar;

- Ukuran meshing: 0,1 x 0,25 meter, max elemen size

- Seakeeping model diam dievaluasi pada arah gelombang $0^{\circ}$ (following sea), $45^{\circ}$ (quartering sea), $90^{\circ}$ (beam sea), $135^{\circ}$, dan $180^{\circ}$ (heading sea), sedang model dengan kecepatan maju (forward speed) disimulasikan hanya pada arah gelombang $180^{\circ}$.

- Kecepatan dianalisis pada $5,144 \mathrm{~m} / \mathrm{s}^{2}$ (10 knot);

- Didasarkan pada gerak harmonic sederhana maka analisa dilakukan pada gerakan: surging ( $s b x)$, swaying ( $s b y$ ), heaving ( $s b z$ ), rolling ( $s b R x$ ), pitching (sb Ry), dan yawing (sb Rz).

\section{Evaluasi seakeeping model diam \\ Hasil RAO Hasil RAO Surge Motion (X)}

Rekapitulasi nilai RAO surgemotion pada pada arah gelombang $0^{\circ}$ (following sea), $45^{\circ}$ (quartering sea), $90^{\circ}$ (beam sea), $135^{\circ}$, dan $180^{\circ}$ (heading sea).

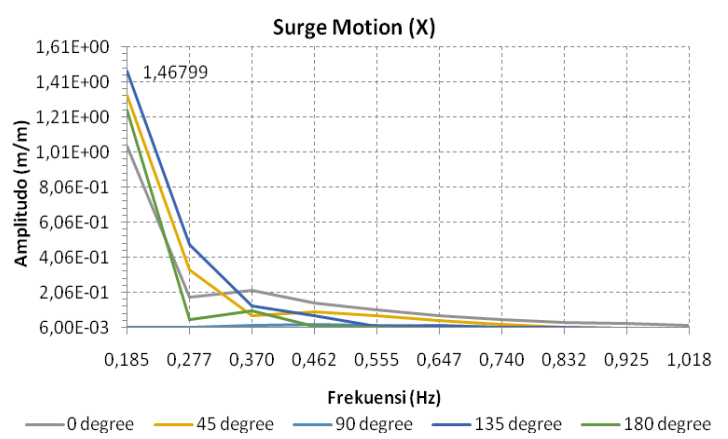

Gambar 16. Grafik RAO surge motion model no speed

Pada surge motion diketahui amplitudo yang tinggi untuk RAOterjadi arah gelombang $45^{\circ}$ 
(quartering sea) dan tertinggipada $135^{\circ}$ sebesar $1,46799(\mathrm{~m} / \mathrm{m})$ pada frekuensi $(\omega) 0.185 \mathrm{~Hz}$.

\section{Hasil RAO Hasil RAO Roll Motion (RX)}

Rekapitulasi nilai RAO rollmotion pada pada arah gelombang $0^{\circ}$ (following sea), $45^{\circ}$ (quartering sea), $90^{\circ}$ (beam sea), $135^{\circ}$, dan $180^{\circ}$ (heading sea).

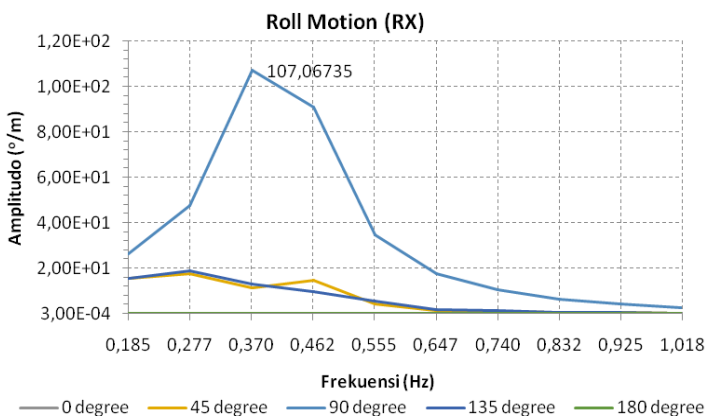

Gambar 17. Grafik RAO roll motion model no speed

Pada roll motion diketahui amplitudo tertinggi untuk RAOterjadi arah gelombang $90^{\circ}$ (beam sea) sebesar 107,0674 (\%) pada frekuensi ( $\omega) 0,37 \mathrm{~Hz}$

\section{Hasil RAO Hasil RAO Sway Motion}

Rekapitulasi nilai RAO swaymotion pada pada arah gelombang $0^{\circ}$ (following sea), $45^{\circ}$ (quartering sea), $90^{\circ}$ (beam sea), $135^{\circ}$, dan $180^{\circ}$ (heading sea).

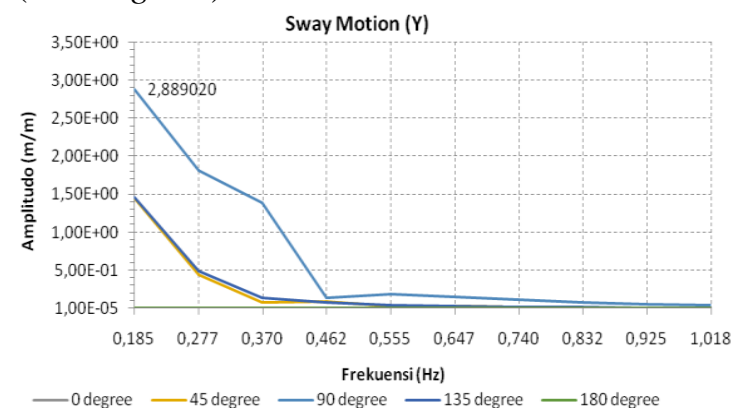

Gambar 18. Grafik RAO sway motion model no speed

Pada sway motion diketahui amplitudo tertinggi untuk RAO terjadi arah gelombang $90^{\circ}$ (Beam Sea) sebesar 2,889 (m/m) pada frekuensi $(\omega)$ $0,185 \mathrm{~Hz}$. Amplitudo untuk RAO arah gelombang $45^{\circ}$ dan $135^{\circ}$ nilainya berhimpit pada frekuensi $(\omega)$ $0,185 \mathrm{~Hz}$ sebesar $\approx 1,45(\mathrm{~m} / \mathrm{m})$.

\section{Hasil RAO Hasil RAO Pitch Motion}

Rekapitulasi nilai RAO pitchmotion pada pada arah gelombang $0^{\circ}$ (following sea), $45^{\circ}$ (quartering sea), $90^{\circ}$ (beam sea), $135^{\circ}$, dan $180^{\circ}$ (heading sea).

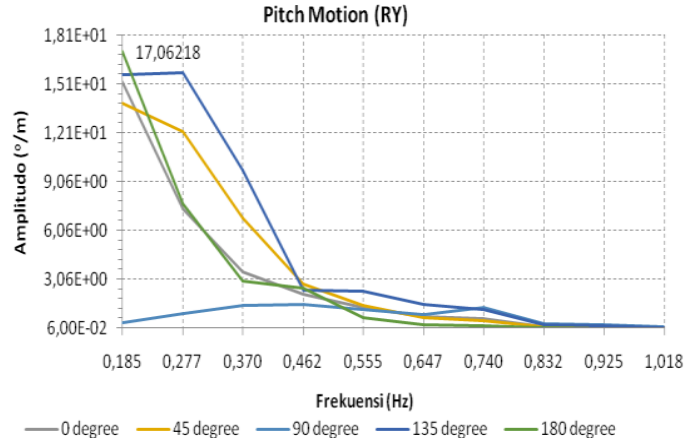

Gambar 19. Grafik RAO pitch motion model no speed

Pada pitch motion diketahui amplitudo tertinggi untuk RAOterjadi arah gelombang $180^{\circ}$ (heading sea) sebesar $17,062(\% \mathrm{~m}$ ) pada frekuensi ( $\omega) 0,185 \mathrm{~Hz}$.

\section{Hasil RAO Hasil RAO Heave Motion}

Rekapitulasi nilai RAO heave motion pada pada arah gelombang $0^{\circ}$ (following sea), $45^{\circ}$ (quartering sea), $90^{\circ}$ (beam sea), $135^{\circ}$, dan $180^{\circ}$ (heading sea)

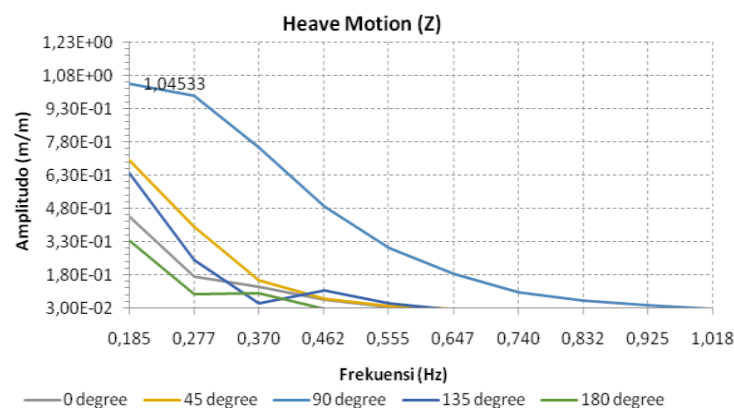

Gambar 20. Grafik RAO heave motion model no speed

Pada heave motion diketahui amplitudo tertinggi untuk RAO terjadi arah gelombang $0^{\circ} 90^{\circ}$ (beam sea) sebesar $1,045(\mathrm{~m} / \mathrm{m})$ pada frekuensi $(\omega)$ $0,185 \mathrm{~Hz}$.

\section{Hasil RAO Hasil RAO Yaw Motion}

Rekapitulasi nilai RAO yaw motion pada pada arah gelombang $0^{\circ}$ (following sea), $45^{\circ}$ (quartering sea), $90^{\circ}$ (beam sea), $135^{\circ}$, dan $180^{\circ}$ (heading sea)

Pada yaw motion diketahui amplitudo tertinggi untuk RAOterjadi padaarah gelombang $45^{\circ}$ (quartering sea) dan $135^{\circ}$ nilainya berhimpit pada frekuensi $(\omega) 0,185 \mathrm{~Hz}$ sebesar $\approx 25,47(\% / \mathrm{m})$. 


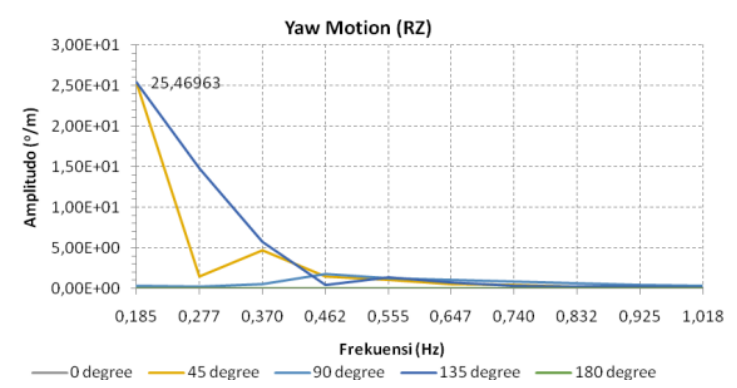

Gambar 21. Grafik RAO yaw motion model no speed

Hasil analisa seakeeping/ olah gerak pada model diam:

- Karakteristik motion untuk gerakan translasional, amplitudo tertinggi terjadi pada RAO sway motion (Y) yang terjadi arah gelombang $90^{\circ}$ (beam sea) sebesar 2,889 (m/m) pada frekuensi ( $\omega) 0.185 \mathrm{~Hz}$.

- Karakteristik motion untuk gerakan rotasional, amplitudo tertinggi terjadi pada RAO roll motion (RX) yang terjadi arah gelombang $90^{\circ}$ (beam sea) sebesar $107,0673(\% \mathrm{~m})$ pada frekuensi $(\omega)$ 0,37 $\mathrm{Hz}$.

\section{Evaluasi seakeeping kecepatan maju (forward speed) arah gelombang $180^{\circ}$}

\section{Rekapitulasi nilai RAO translational motion}

Rekapitulasi nilai RAO translational motion pada kecepatan maju (forward speed) arah gelombang $180^{\circ}$.

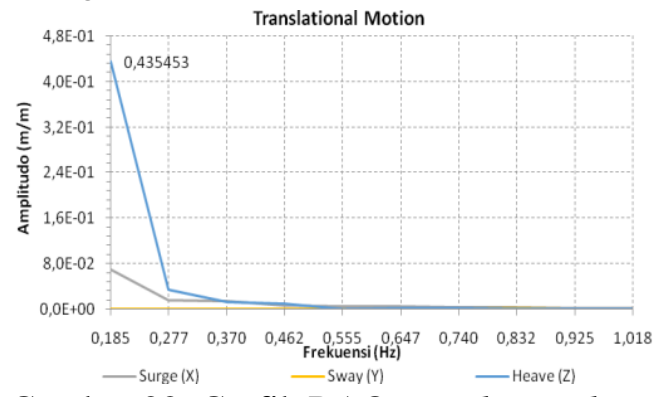

Gambar 22. Grafik RAO translational motion model forward speed 35 knot

\section{Rekapitulasi nilai RAORotationalMotion}

Rekapitulasi nilai RAO rotational motion pada kecepatan maju (forward speed) arah gelombang $180^{\circ}$.

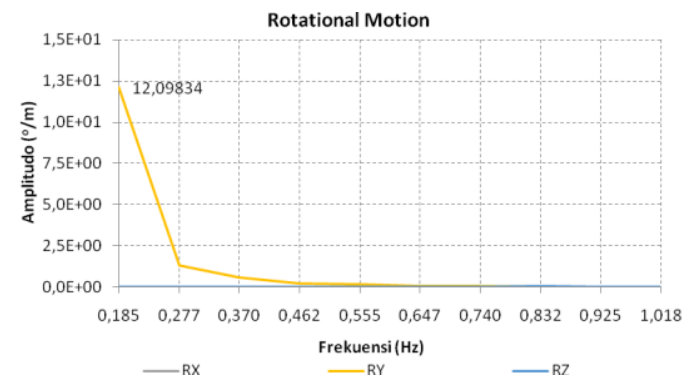

Gambar 23. Grafik RAO rotational motion model forward speed $35 \mathrm{knot}$
Hasil analisis seakeeping/ olah gerak pada kecepatan maju (forward speed) arah gelombang 180':

- Pada translational motion diketahui amplitudo tertinggi terjadi pada RAOheave motion (X) sebesar $0,4354(\mathrm{~m} / \mathrm{m})$ pada frekuensi $(\omega) 0,185$ Hz.

- Pada rotational motion diketahui amplitudo tertinggi terjadi pada RAO pitchmotion (RY) sebesar $12,098(\mathrm{o} / \mathrm{m})$ pada frekuensi $(\omega) 0,185$ Hz.

\section{SIMPULAN}

Guna mendapatkan model yang optimum maka analisis dilakukan dengan variasi model pada perubahan sudut untuk model hull dengan rise of floor yang diidentifikasi sebagai RF 0, RF 1, RF 2, RF 3, RF 4, dan RF 5. Berdasarkan pemodelan, perhitungan dan analisis untuk model hull dengan rise of floor yang telah dilakukan dihasilkan:

a. Kecocokan model dalam segi ukuran utama kapal dan karakteristik kapal dengan melihat pada item calculate hydrostatic pada Maxsurf. Hasil koreksi perbedaan antara model hull dengan rise of floor: RF 2, RF 3, RF 4, dan RF 5 menunjukkan bahwa toleransi kesamaan displacement $<5 \%$. Sehingga dapat dikatakan masing-masing model hull dengan rise of floor sudah memenuhi untuk dilakukan analisis selanjutnya.

b. Hasil analisis terhadap seluruh model hull didapatkan hambatan terkecil dihasilkan dari model hull RF 5 sebesar 5,04 kN, sedangkan power (EHP) terkecil dihasilkan dari model hull RF 1 sebesar 50,39 hp.

c. Dengan power kapal yang tetap di perairan dalam maka koreksi resistance untuk kondisi perairan dangkal dengan perbandingan kedalaman air dan sarat kapal, $\mathrm{h} / \mathrm{d}=1.2$. Dari hasil koreksi pada kondisi perairan yang dangkal $(\mathrm{h}=0,85 \mathrm{~m})$ maka hambatan kapal mengalami kenaikan yang besar. Perbandingan model hull yang paling kecil mengalami kenaikan hambatan ditunjukkan model hull RF 0.

d. Hasil analisis stabilitas didapatkan:

Dari hasil analisis stabilitas kondisi muatan kosong (lightship) dan kondisi full load (displacement) menunjukkan bahwa persyaratan stabilitas kapal memenuhi kriteria dari persyaratan IMO.

e. Hasil analisis seakeeping/olah gerak

1) Model diam didapatkan:

- Karakteristik motion untuk gerakan translasional, amplitudo tertinggi terjadi pada RAO sway motion (Y) yang terjadi arah gelombang $90^{\circ}$ (beam sea) sebesar $2,889(\mathrm{~m} / \mathrm{m})$ pada frekuensi $(\omega) 0.185 \mathrm{~Hz}$. 
- Karakteristik motion untuk gerakan rotasional, amplitudo tertinggi terjadi pada $\mathrm{RAO}$ roll motion (RX) yang terjadi arah gelombang $90^{\circ}$ (beam sea) sebesar 107,0673 $(\% \mathrm{~m})$ pada frekuensi $(\omega) 0,37 \mathrm{~Hz}$.

2) Model dengan speed 10 knot didapatkan:

3) Pada translational motion diketahui amplitudo tertinggi terjadi pada RAO heave motion (X) sebesar $0,4354(\mathrm{~m} / \mathrm{m})$ pada frekuensi $(\omega) 0,185$ $\mathrm{Hz}$.

4) Pada rotational motion diketahui amplitudo tertinggi terjadi pada RAO pitch motion (RY) sebesar $12,098(\mathrm{o} / \mathrm{m})$ pada frekuensi $(\omega) 0,185$ $\mathrm{Hz}$.

\section{DAFTAR PUSTAKA}

Anggara, S., 2013, Studi Komparatif Performa Hidrodinamik Kapal Bertipe Shallow Draft Barge pada Kondisi Perairan Dangkal, Sedang dan Dalam, Tesis, FTK-ITS.

Barras, C.B. and Derret, D.R., 2006, "Ship Stability for Masters \& Mates", sixth edition. London.

Barrass,C.B., 1979, "Ship-handling problems in shallow water", MER, November.

Bhattacharyya, R., 1978, "Dynamics of Marine Vehicles", John Wiley \& Sons.

Chakrabarti, S.K., 1987, "Hydrodynamics of Offshore Structures", Southampton: WIT Press.

Lackenby, H., 1962, "The resistance of ships with special reference to skin friction and hull surface conditions", Proceedings of the Institution of Mechanical Engineers, London: 176, 981-1014.

Lewis, E.V., 1988, "Principle of Naval Architecture Vol II: Resistance, Propulsion and Vibration", Published: The Society of Naval Architects and Marine Engineers.

Lyon, T.D. and Mistree, F., 1985, "A ComputerBased Method for the Preliminary Design of Ships", Journal of Ship Research, Vol. 29, No. 4, Dec, p. 251-269.

Molland, A.F., Turnock, R.S. and Hudson, D.A., 2011, "Ship Resistance and Propulsion: Practical Estimation of Propulsive Power", Cambridge University Press.

Nordic Project Board, 1987, "Assessment of Ship Performance in a Seaway", Nord-Forsk, Nordic Cooperative Project: Seakeeping performance of ships, Copenhagen Denmark.

O'Hanlon, J.F., and McCauley, M.E., 1974, "Motion Sickness Incidence As a Function of the Frequency and Acceleration of Vertical Sinusoidal Motion". Santa Barbara, CA: Human Factors Research, Inc.

Sulistyawati, W., 2013, Optimasi Ukuran Utama dan Studi Parametrik Bulk Carrier untuk Perairan dangkal, Tesis, Fakultas Teknologi Kelautan, ITS.

Taggart, R., Ed., 1980, "Ship Design and Contruction", The Society of Naval Architect \& Marine Engineers.

Toursethaugen, K., et al, 1984, "Characteristica for Extreme Sea States on the Norwegian Continental Shelf', Technical Report No. STF60 A84123, Norwegian Hydrodyn, Lab., Trondheim.

Watson, D.G.M., 1998, "Practical Ship Design", Volume I. Oxford, UK: Elsevier Science Ltd.

Bambang Sudjasta dkk, 2011, Prototipe Rancangan Kapal Tipe Pendarat 200 GRT Sebagai Sarana Penyeberangan Antar Pulau Di Daerah Terpencil Kepulauan Indonesia, Jurnal Ilmiah FT-UPNVJ Bina Teknika Volume 7 Nomor 2 Edisi November.

Bambang Sudjasta dkk, 2012, Perancangan Bis Air Kapasitas 40 Penumpang Sebagai Sarana Transportasi Alternatif Pada Kanal Banjir Timur Provinsi DKI Jakarta, Jurnal Ilmiah FTUPNVJ Bina Teknika Volume 8 Nomor 2 Edisi Desember.

Bambang Sudjasta, Iswadi Nur, 2008, Pengaruh Angin Terhadap Kecepatan Kapal Penumpang 500 PAX, Jurnal Ilmiah FT-UPNVJ Bina Teknika Volume 4 Nomor 1 Edisi Februari.

Iswadi Nur, 2012, Penggunaan Skala 1 : 1 Dan Pengukuran Shipsectional Area Dalam Penggambaran Bentuk Badan Kapal Secara Manual Dengan Metode RF. Sceltema Deheere, Jurnal Ilmiah FT-UPNVJ Bina Teknika Volume 8 Nomor 1 Edisi Juni.

Iswadi Nur, 2013, Metode Sederhana Memilih Jenis Lambung Kapal Kecil (Boat) Sesuai Fungsinya Berdasarkan Pertimbangan Stabilitas Agar Dapat Menghindari Kecelakaan Di Laut, Jurnal Ilmiah FT-UPNVJ Bina Teknika Volume 9 Nomor 2 Edisi Desember.

Wiwin Sulistyawati, 2014, Optimasi Ukuran Utama dan Studi Parametrik Bentuk Bulk Carrier Untuk Perairan Dangkal, Jurnal Ilmiah FTUPNVJ Bina Teknika Volume 10 Nomor 1 Edisi Juni. 